\title{
Stability indicating RP-HPLC method for the determination of Tramadol Hydrochloride in Sterile Dosage form
}

\author{
K. Dhanalakshmi ${ }^{\star 1}$, S. Sumitha ${ }^{1}$, and S. Sivaramakrishnan ${ }^{2}$ \\ 'Department of Pharmaceutical Chemistry, Manonmaniam Sundaranar University \\ Tirunelveli-627012, India \\ ${ }^{2}$ Caplin Point Laboratories, Chennai - 601201, India
}

\begin{abstract}
A simple, well-organized and reproducible RP-HPLC method for determination of Tramadol Hydrochloride injection dosage form has been developed and validated. The Chromatographic Separation was carried out on Zorbax $C_{8}(250 \times 4.6 \mathrm{~mm} ; 5 \mu \mathrm{m})$ column using the mobile phase consists of buffer and Acetonitrile in the ratio 65:35. The mobile phase was flowed at the rate of $0.1 \mathrm{ml} / \mathrm{min}$ and effluent was detected at $270 \mathrm{~nm}$. The retention time of Tramadol Hydrochloride was 4.273 min. The method was validated according to ICH guidelines and the acceptance criteria for specificity, linearity, accuracy, precision, robustness, and ruggedness were met in all cases. The method was linear in the range of $50 \mu \mathrm{g} / \mathrm{ml}$ of Tramadol Hydrochloride. The percentage relative standard deviation for precision was found to be less than $2.0 \%$.

Keywords: Tramadol Hydrochloride, RP-HPLC, Sterile dosage form, Stability indicating method.
\end{abstract}

\section{Introduction}

Tramadol Hydrochloride is a class of drug called analgesic drugs. It works by narcotic to relieve pain in the body. It is used to relieve the moderate and severe pain in the body. The analgesic effect of Tramadol Hydrochloride may result from the narcotic inhibitor. Tramadol Hydrochloride belongs to amino cyclohexanol group $^{(1-5)}$.Various analytical methods had reported in literature for the estimation of Tramadol Hydrochloride individually and in combination with other drugs by HPLC method ${ }^{(6-7)}$, UV Spectrophotometry, Reversed phase ion pair High performance liquid chromatography, and by Mass spectrophotometry ${ }^{(8-10)}$ in oral dosage form. In this present work, an attempt was made to develop an easy, sufficient stability indicating method for the estimation of Tramadol Hydrochloride in sterile dosage form by RP-HPLC. The proposed method was validated in accordance with International Conference on Harmonization (IHC) guidelines.

International Journal of PharmTech Research, 2018,11(3): 226-234.

DOI: http://dx.doi.org/10.20902/IJPTR.2018.11304 
The chemical name for tramadol hydrochloride is $( \pm)$ cis-2[(dimethylamino) methyl]-1-(3methoxyphenyl) cyclohexanol hydrochloride. Its structural formula is-<smiles>COc1cccc(C2(O)CCCCC2CN(C)C)c1</smiles>

Figure No 1: Structure of Tramadol Hydrochloride

\section{Materials and Methods}

Chemicals: Pure standards of Tramadol Hydrochloride Injection $50 \mathrm{mg} / \mathrm{mL}$ were purchased from SigmaAldrich India. HPLC grade acetonitrile, water, and Trifluoracetic acid were purchased from Fischer scientific and other chemicals used were analytical grade.

\section{Chromatographic Conditions:}

Instrument $:$ Agilent HPLC or equivalent
Column $:$ Zorbax $\mathrm{C}_{8},(250 \times 4.6 \mathrm{~mm}), 5 \mu \mathrm{m}$
Pump Mode $:$ Isocratic
Flow Rate $: 1.0 \mathrm{~mL} /$ minute
Detector Wavelength $\quad: 270 \mathrm{~nm}$
Column Oven Temperature $\quad:$ Ambient
Sample Cooler Temperature $\quad:$ Ambient
Injection volume
Run Time

\section{Preparation of Buffer:}

Mix $2 \mathrm{~mL}$ of Trifluoracetic Acid in $1000 \mathrm{~mL}$ of water and filter through 0.45 membrane filter.

\section{Preparation of Mobile Phase:}

Prepare a degassed mixture of buffer and Acetonitrile in ratio of 65:35 v/v.

\section{Preparations of standard solution:}

Accurately weigh about $50 \mathrm{mg}$ of Tramadol Hydrochloride working standard into a $100 \mathrm{~mL}$ volumetric flask, add about $60 \mathrm{~mL}$ of diluent, sonicate to dissolve and dilute to volume with diluent and mix. Further dilute $5 \mathrm{~mL}$ of the solution into $25 \mathrm{~mL}$ volumetric flask, make up the volume with diluent and mix.

\section{Preparation of sample solution:}

Transfer $2 \mathrm{~mL}$ of standard solution into $100 \mathrm{~mL}$ volumetric flask, add $60 \mathrm{~mL}$ of diluent mix and make up the volume with diluents and mix. Further dilute $5 \mathrm{~mL}$ of the solution to $50 \mathrm{~mL}$ with diluent, mix and filter through 0.45 Nylon membrane filter.

\section{Procedure:}

Inject diluent (blank) into the chromatograph and record the chromatogram. Inject standard solution in five replicate injections into the chromatograph and record the chromatograms and then Inject sample solutions in duplicate injections into the chromatograph and record the chromatograms. 


\section{Calculation:}

$$
\begin{aligned}
& \text { Assay }(\mathrm{mg} / \mathrm{mL}) \text { of Tramadol Hydrochloride }\left(\mathrm{C}_{16} \mathrm{H}_{25} \mathrm{NO}_{2 .} \mathrm{HCL}\right):=\frac{A_{T}}{A_{S}} \times \frac{D_{S}}{D_{T}} \times \frac{p}{100} \\
& \% \text { Labeled Amount: }=\frac{\operatorname{Assay}\left(\frac{\mathrm{mg}}{\mathrm{mL}}\right)}{L C} \times 100
\end{aligned}
$$

Where, $\mathrm{A}_{\mathrm{T}}$ : Average area of Tramadol peak obtained from the sample chromatogram, $\mathrm{A}_{\mathrm{s}}$ : Average area of Tramadol peak obtained from the standard chromatogram, $\mathrm{D}_{\mathrm{S}}$ : Dilution factor for standard preparation, $\mathrm{D}_{\mathrm{T}}$ : Dilution actor for sample preparation, P: Percentage purity of Tramadol Hydrochloride working standard, LC: Label claim for Tramadol Hydrochloride in tramadol HCL Injection $(50 \mathrm{mg} / \mathrm{mL})$.

\section{Results and Discussion}

\section{Specificity}

The specificity of the HPLC method is illustrated in Fig.2a-b, where a complete separation of Tramadol Hydrochloride was noticed in presence of other inactive excipients used in injections. In addition, there was no interference at the retention time in the chromatogram of placebo solution. In peak purity analysis with DAD, purity angle was always less than purity threshold for the analyte. This shows that the peaks of analyte were pure and excipients in the formulation does not interfere the analyte. The data of retention time and area of the analyte in standard and sample were presented in the Table no 1.

\section{Linearity}

The Linearity of this method was determined at seven levels from 50\%-150\% of operating concentrations for Tramadol Hydrochloride. The Plots of peak area of each sample against respective concentration of Tramadol Hydrochloride were found to be linear in the range of $50 \%-150 \%$ of operating concentrations. Beer's law was found to be obeyed over this concentration range. The linearity was evaluated by linear regression analysis using least square method. The linear regression equations and correlation coefficient were found. It observed that correlation coefficient and regression analysis were within the limits which shown in the table no 2 and fig no 3.

\section{Precision}

The precision of an analytical procedure expresses the closeness of agreement between a series of measurements obtained from multiple sampling of the homogenous sample under the prescribed conditions.

\section{Reproducibility}

Reproducibility examines the precision between laboratories and it is often determined in collaborative studies. Reproducibility data for Tramadol Hydrochloride is expressed in \%RSD and it was less than $2 \%$ ( Table no 3) which indicates that the method was highly precise.

\section{Repeatability}

Repeatability is the precision of the method under the same operating conditions over a short period. A second aspect is sometimes termed intra-assay precision and involves multiple measurements of the same sample by the same analyst under the same conditions. Repeatability data for Tramadol Hydrochloride is expressed in $\%$ RSD and it was less than 2\% (Table no 4)which indicates that the method was highly precise.

\section{Accuracy}

Accuracy of the method was found out by recovery study by standard addition method. The known amounts of standard Tramadol Hydrochloride were added to pre-analyzed samples at a level from 75\% up to $125 \%$ and then subjected to the proposed HPLC method individually. It was observed that good recoveries of Tramadol Hydrochloridewere obtained at each added concentration level shown in table no 5 which demonstrated that the method was highly accurate. 


\section{Robustness}

The Measure of a method capacity remains unaffected by small, but deliberate variation in method. Robustness of the Tramadol Hydrochloride was carried out by varying some chromatographic method parameters. The sample preparations were analyzed as per methodology by changing the ratio of solvents in the mobile phase and flow rate by means of $+10 \%$ or $-10 \%$. it was observed and shown in the table no 6 that there were no marked changes in the chromatograms, which demonstrated that the proposed method was robust.

\section{Ruggedness}

Six sample preparations were analyzed as per the methodology by a different analyst on a different instrument on a different day. The ruggedness data for Tramadol Hydrochloride were observed and shown in the table no 7 that there were no marked changes in the chromatogram, which demonstrated that, the proposed method of ruggedness.

\section{Forced Degradation}

The study was intended to ensure the effective separation of Tramadol Hydrochloride and its degradation peaks of formulation ingredients at the retention time of Tramadol Hydrochloride. Forced degradation studies were performed to evaluate the stability indicating properties and specificity of the method. The samples were subjected to various forced degradation conditions and percentage of degradation under various treatment conditions were calculated. The evaluation of chromatographic peak response of the analyte from every degradation method is shown in the table no 8 which is homogeneous and free of co-eluting peaks.

\section{Stability Studies}

Standard and Sample solutions were prepared as per test method, analyzed initially and at different time intervals by keeping the solutions at room temperature $\left(\sim 25^{\circ} \mathrm{C}\right)$ the results are shown in table no 9 which indicates the method was stable.

Table No. 1: Specificity for Tramadol Hydrochloride

\begin{tabular}{|l|l|c|c|c|}
\hline S. No & $\begin{array}{l}\text { Name of the } \\
\text { solution }\end{array}$ & $\begin{array}{l}\text { No. of } \\
\text { Injections }\end{array}$ & $\begin{array}{c}\text { Retention } \\
\text { Time (min.) }\end{array}$ & $\begin{array}{l}\text { Peak } \\
\text { Purity }\end{array}$ \\
\hline 1. & Blank & 1 & Nil & - \\
\hline 2. & Placebo & 1 & Nil & - \\
\hline 3. & Standard & 1 & 4.273 & 1.000000 \\
\hline 4. & Sample & 1 & 4.273 & 1.000000 \\
\hline
\end{tabular}

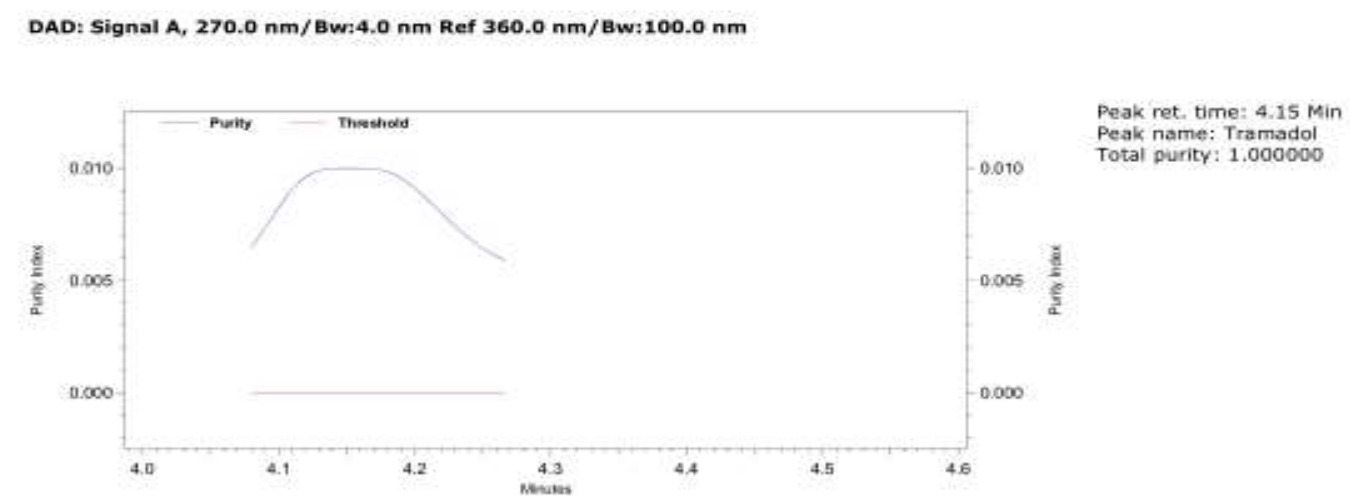

Figure No.2a: Chromatogram for the study of Standard peak purity 


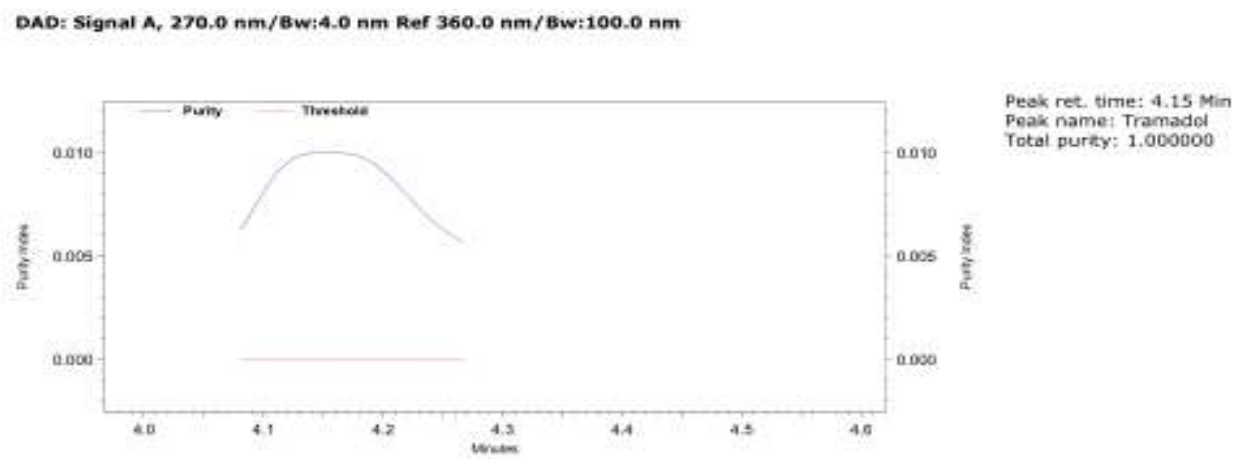

Figure No.2b: Chromatogram for the study of Sample peak purity

Table No. 2: Linearity of response for Tramadol Hydrochloride

\begin{tabular}{|c|c|c|c|c|c|}
\hline S.No & $\begin{array}{c}\text { Target level } \\
\%\end{array}$ & $\begin{array}{c}\text { Concentration } \\
(\mu \mathrm{g} / \mathrm{mL})\end{array}$ & Area 1 & Area 2 & Average Area \\
\hline 1. & 50 & 50.5 & 33173142 & 33185861 & 33179502 \\
\hline 2. & 80 & 80.8 & 53512875 & 53505383 & 53509129 \\
\hline 3. & 90 & 91.0 & 60294697 & 60307583 & 60301140 \\
\hline 4. & 100 & 101.1 & 67169933 & 67014936 & 67092435 \\
\hline 5. & 110 & 111.2 & 73793351 & 73854643 & 73823997 \\
\hline 6. & 120 & 121.3 & 81144883 & 81170148 & 81157516 \\
\hline 7. & 150 & 151.6 & 101069546 & 101101702 & 101085624 \\
\hline \multicolumn{5}{|r|}{ Slope } & 673067 \\
\hline \multicolumn{5}{|r|}{ Intercept } & -863664 \\
\hline \multicolumn{5}{|c|}{$\%$ Y-Intercept } & -1.3 \\
\hline \multicolumn{5}{|c|}{ Residual Sum of Squares } & 196875 \\
\hline \multicolumn{5}{|c|}{ Correlation Coefficient } & 0.99996 \\
\hline
\end{tabular}

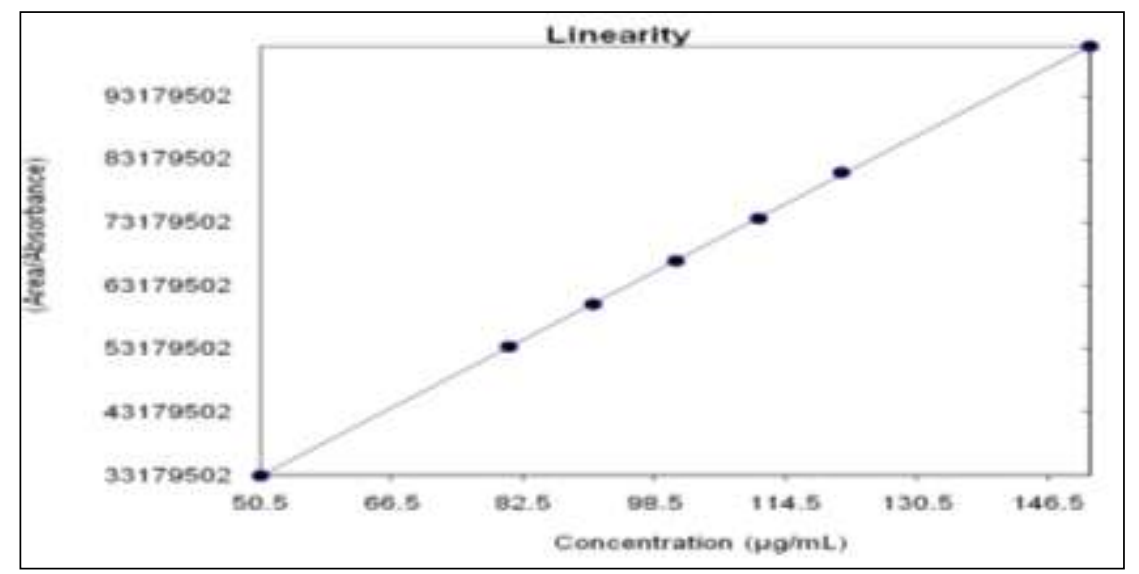

Figure No.3: Linearity curve for Tramadol Hydrochloride 
Table No. 3: Precision- Reproducibility for Tramadol Hydrochloride

\begin{tabular}{|c|c|c|c|c|c|c|}
\hline S.No & StdInjection & Area & Mean & SD & \% RSD & $\begin{array}{c}\text { 95\% Confidence } \\
\text { Interval ( } \pm \text { ) }\end{array}$ \\
\hline 1. & 1 & 1033207 & & & & \\
\hline 2. & 2 & 1033344 & & & & $\mathbf{2}$ \\
\cline { 1 - 3 }. & 3 & 1033214 & \multirow{2}{*}{$\mathbf{1 0 3 3 4 2 4}$} & $\mathbf{2 8 2}$ & $\mathbf{0 . 1}$ & \\
\hline 4. & 4 & 1033757 & & & \\
\hline 5. & 5 & 1033806 & & & & \\
\hline 6. & 6 & 1033215 & & & &
\end{tabular}

Table No. 4: Method Precision-Repeatability for Tramadol Hydrochloride

\begin{tabular}{|c|c|c|c|c|c|}
\hline $\begin{array}{c}\text { S. } \\
\text { No }\end{array}$ & Sample Name & Area & Average Area & $\begin{array}{c}\text { Amount of drug } \\
\text { present } \\
(\mathrm{mg} / \mathrm{mL})\end{array}$ & $\begin{array}{c}\text { Drug } \\
\text { Recovery }(\%)\end{array}$ \\
\hline \multirow[t]{2}{*}{1.} & Sample 1-1 & 66158179 & \multirow[t]{2}{*}{66138374} & \multirow[t]{2}{*}{51.37} & \multirow[t]{2}{*}{102.7} \\
\hline & Sample 1-2 & 66118568 & & & \\
\hline \multirow[t]{2}{*}{2.} & Sample 2-1 & 65630743 & \multirow[t]{2}{*}{65566450} & \multirow[t]{2}{*}{50.92} & \multirow[t]{2}{*}{101.8} \\
\hline & Sample 2-2 & 65502156 & & & \\
\hline \multirow[t]{2}{*}{3.} & Sample 3-1 & 65419658 & \multirow[t]{2}{*}{65424980} & \multirow[t]{2}{*}{50.81} & \multirow[t]{2}{*}{101.6} \\
\hline & Sample 3-2 & 65430302 & & & \\
\hline \multirow[t]{2}{*}{4.} & Sample 4-1 & 65382543 & \multirow[t]{2}{*}{65367372} & \multirow[t]{2}{*}{50.77} & \multirow[t]{2}{*}{101.5} \\
\hline & Sample 4-2 & 65352200 & & & \\
\hline \multirow[t]{2}{*}{5.} & Sample 5-1 & 65541166 & \multirow[t]{2}{*}{65458170} & \multirow[t]{2}{*}{50.84} & \multirow[t]{2}{*}{101.7} \\
\hline & Sample 5-2 & 65530361 & & & \\
\hline & & & & Mean & 101.7 \\
\hline & & & & SD & 0.22 \\
\hline & & & & \%r RSD & 0.4 \\
\hline \multicolumn{5}{|c|}{ 95\% Confidence Interval $( \pm)$} & 0.2 \\
\hline
\end{tabular}

Table No. 5: Accuracy for Tramadol Hydrochloride

\begin{tabular}{|c|c|c|c|c|}
\hline S.No & Target Level & Area & $\begin{array}{c}\text { Amount of drug } \\
\text { present (mg) }\end{array}$ & \% Recovery \\
\hline 1. & $75 \%$ Sample-1 & 48697834 & 74.01 & 98.7 \\
\hline 2. & $75 \%$ Sample-2 & 48812848 & 74.19 & 99.1 \\
\hline 3. & $75 \%$ Sample-3 & 48682410 & 73.99 & 99.0 \\
\hline 4. & $100 \%$ Sample-1 & 64934210 & 98.69 & 98.8 \\
\hline 5. & $100 \%$ Sample-2 & 64828265 & 98.53 & 98.7 \\
\hline 6. & $100 \%$ Sample-3 & 64852978 & 98.56 & 98.7 \\
\hline 7. & $125 \%$ Sample-1 & 81371140 & 123.67 & 98.9 \\
\hline 8. & $125 \%$ Sample-2 & 81289914 & 123.54 & 98.8 \\
\hline 9. & $125 \%$ Sample-3 & 81434938 & 123.76 & 99.2 \\
\hline \multicolumn{7}{|r}{} & Mean & $\mathbf{9 8 . 8}$ \\
\hline \multicolumn{7}{|r}{} & SD & $\mathbf{0 . 3}$ \\
\hline
\end{tabular}


Table No. 6: Robustness of Tramadol Hydrochloride

\begin{tabular}{|l|l|c|c|c|c|c|c|}
\hline $\begin{array}{c}\text { S. } \\
\text { No }\end{array}$ & Parameter & Variation & Area & Mean & SD & \% RSD & $\begin{array}{c}\text { RT } \\
(\mathbf{m i n})\end{array}$ \\
\hline 1. & Flow Rate & $-10 \%$ & 72815900 & 72814061 & 69463 & 0.1 & 4.580 \\
\cline { 3 - 8 } & & $+10 \%$ & 59574226 & 59524539 & 48608 & 0.1 & 3.747 \\
\hline 2. & $\begin{array}{l}\text { Organic in } \\
\text { mobile phase }\end{array}$ & $-2 \%$ absolute & 65488147 & 65481014 & 54360 & 0.1 & 4.520 \\
\cline { 3 - 8 } & & $+2 \%$ absolute & 65850385 & 65800312 & 42239 & 0.1 & 3.793 \\
\hline
\end{tabular}

Table No. 7: Ruggedness of Tramadol Hydrochloride

\begin{tabular}{|c|c|c|c|c|c|}
\hline S.No & Sample Name & Area & Average Area & $\begin{array}{c}\text { Content in } \\
\text { mg/Unit }\end{array}$ & $\begin{array}{c}\text { \% Labeled } \\
\text { Amount }\end{array}$ \\
\hline \multirow[t]{2}{*}{1.} & Sample 1-1 & 1052899 & \multirow[t]{2}{*}{1053015} & \multirow[t]{2}{*}{50.82} & \multirow[t]{2}{*}{101.6} \\
\hline & Sample 1-2 & 1053130 & & & \\
\hline \multirow[t]{2}{*}{2.} & Sample 2-1 & 1052565 & \multirow[t]{2}{*}{1054913} & \multirow[t]{2}{*}{50.91} & \multirow[t]{2}{*}{101.8} \\
\hline & Sample 2-2 & 1057261 & & & \\
\hline \multirow[t]{2}{*}{3.} & Sample 3-1 & 1054797 & \multirow[t]{2}{*}{1055202} & \multirow[t]{2}{*}{50.93} & \multirow[t]{2}{*}{101.9} \\
\hline & Sample 3-2 & 1055607 & & & \\
\hline \multirow[t]{2}{*}{4.} & Sample 4-1 & 1051808 & \multirow[t]{2}{*}{1051648} & \multirow[t]{2}{*}{50.76} & \multirow[t]{2}{*}{101.5} \\
\hline & Sample 4-2 & 1051488 & & & \\
\hline \multirow[t]{2}{*}{5.} & Sample 5-1 & 1054241 & \multirow[t]{2}{*}{1051648} & \multirow[t]{2}{*}{50.89} & \multirow[t]{2}{*}{101.8} \\
\hline & Sample 5-2 & 1054477 & & & \\
\hline \multirow[t]{2}{*}{6.} & Sample 6-1 & 1053446 & \multirow[t]{2}{*}{1053562} & \multirow[t]{2}{*}{50.85} & \multirow[t]{2}{*}{101.7} \\
\hline & Sample 6-2 & 1053678 & & & \\
\hline \multicolumn{5}{|r|}{ Mean } & $\mathbf{5 0 . 9 0}$ \\
\hline \multicolumn{5}{|r|}{ SD } & 0.16 \\
\hline \multicolumn{5}{|r|}{ RSD (\%) } & 0.3 \\
\hline \multicolumn{5}{|c|}{ 95\% Confidence Interval $( \pm)$} & 0.1 \\
\hline
\end{tabular}

Table No.8: Forced Degradation of Tramadol Hydrochloride

\begin{tabular}{|c|c|c|c|c|c|}
\hline S.No & Sample treatment condition & Area & $\begin{array}{c}\text { Content in } \\
(\mathbf{m g} / \text { Unit) }\end{array}$ & $\begin{array}{c}\text { \% Labeled } \\
\text { amount }\end{array}$ & $\begin{array}{c}\% \\
\text { Degradation }\end{array}$ \\
\hline 1. & $\begin{array}{c}\text { Acid Degradation(2NHCl) } \\
85^{\circ} \mathrm{C} / 30 \text { minutes }\end{array}$ & 65778085 & 50.31 & 100.6 & 1.0 \\
\hline 2. & $\begin{array}{c}\text { Acid Degradation(2NHCl) } \\
85^{\circ} \mathrm{C} / 60 \text { minutes }\end{array}$ & 66098774 & 50.56 & 101.1 & 0.5 \\
\hline 3. & $\begin{array}{c}\text { Base Degradation } 2 \mathrm{NNaOH} \\
85^{\circ} \mathrm{C} / 30 \text { minutes }\end{array}$ & 65666516 & 50.23 & 100.5 & 1.2 \\
\hline 4. & $\begin{array}{c}\text { Base Degradation } 2 \mathrm{NNaOH} \\
85^{\circ} \mathrm{C} / 60 \text { minutes }\end{array}$ & 66031676 & 50.51 & 101.0 & 1.6 \\
\hline 5. & $\begin{array}{c}\text { Peroxide Degradation } 10 \% \\
\mathrm{H}_{2} \mathrm{O}_{2} 85^{\circ} \mathrm{C} / 30 \text { minutes }\end{array}$ & 65701677 & 50.26 & 100.5 & 1.0 \\
\hline 6. & $\begin{array}{c}\text { Peroxide Degradation } 10 \% \\
\mathrm{H}_{2} \mathrm{O}_{2} 85^{\circ} \mathrm{C} / 30 \text { minutes }\end{array}$ & 65758098 & 50.30 & 100.6 & 1.1 \\
\hline
\end{tabular}




\section{Stability Studies}

Standard and Sample solutions were prepared as per test method, analyzed initially and at different time intervals by keeping the solutions at room temperature $\left(\sim 25^{\circ} \mathrm{C}\right)$ the results are shown in table no 9 wich indicates the method was stable.

Table No.9:Stability studies for Tramadol Hydrochloride

\begin{tabular}{|c|c|c|c|c|}
\hline \multirow{2}{*}{ Time } & \multicolumn{2}{|c|}{ Standard Solution } & \multicolumn{2}{c|}{ Sample Solution } \\
\cline { 2 - 5 } & Area & \% Difference & Area & \% Difference \\
\hline Initial & 1028744 & - & 1052591 & - \\
\hline 1 Hour & 1031378 & -0.3 & 1056409 & -0.4 \\
\hline 2 Hours & 1031969 & -0.3 & 1056055 & -0.3 \\
\hline 3 Hours & 1032463 & -0.4 & 1057170 & -0.4 \\
\hline 4 Hours & 1032565 & -0.4 & 1059101 & -0.6 \\
\hline 5 Hours & 1033653 & -0.5 & 1060425 & -0.7 \\
\hline 6 Hours & 1034839 & -0.6 & 1061564 & -0.9 \\
\hline 7 Hours & 1036163 & -0.7 & 1062662 & -1.0 \\
\hline 8 Hours & 1036814 & -0.8 & 1064900 & -1.2 \\
\hline 10 Hours & 1038954 & -1.0 & 1064712 & -1.2 \\
\hline 11 Hours & 1039191 & -1.0 & 1066850 & -1.4 \\
\hline 12 Hours & 1038510 & -0.9 & 1068902 & -1.5 \\
\hline 13 Hours & 1039328 & -1.0 & 1064764 & -1.2 \\
\hline 14 Hours & 1041095 & -1.2 & 1067743 & -1.4 \\
\hline 15 Hours & 1040713 & -1.2 & 1067060 & -1.4 \\
\hline 24 Hours & 1033632 & -0.5 & 1070313 & -1.7 \\
\hline 29 Hours & 1029574 & -0.1 & 1066120 & -1.3 \\
\hline 34 Hours & 1028653 & 0.0 & 1067186 & -1.4 \\
\hline 39 Hours & 1027827 & 0.1 & 1067411 & -1.4 \\
\hline 48 Hours & 1029099 & 0.0 & 1068937 & -1.6 \\
\hline
\end{tabular}

\section{Conclusion}

The Proposed study describes a simple, feasible and sensitive reverse-phase high-performance liquid chromatographic method for quantitative determination of Tramadol Hydrochloride in sterile dosage form. The method was validated as per ICH guidelines and found to be simple, specific, linear and precise. Therefore, the proposed method can be successfully used for the routine analysis of Tramadol Hydrochloride in pharmaceutical dosage form without interference.

\section{Acknowledgement}

The author thanks Caplin Point Laboratories, Chennai - 601201, India for providing the Lab facilities to do research work.

\section{References}

1. www.drugbank.com

2. www.sciencedirect.com

3. www.googlescholar.com

4. $\quad$ www.pubmed.com

5. www.mhra.gov.uk

6. Gan, S. H., Ismail, R., Wan Adnan, W. A., \& Wan, Z. (2002). Method development and validation of a high-performance liquid chromatographic method for tramadol in human plasma using liquid-liquid 
extraction. Journal of Chromatography. B, Analytical Technologies in the Biomedical and Life Sciences, 772(1), 123-129. doi:10.1016/S1570-0232(02)00065-X.

7. Alireza Foroumadi. (2006). Mohammad-Reza Rouini, YaldaHosseinzadehArdakani, FaezehSoltani, Hassan. Y, Aboul-Enein, Development and validation of a rapid HPLC method for simultaneous determination of tramadol, and its two main metabolites in human plasma. Journal of Chromatography. A, 830(2), 207-211.

8. Küçük, A., \& Kadığlu, Y. (2005). Determination of tramadol hydrochloride in ampoule dosage forms by using UV spectrophotometric and HPLC-DAD methods in methanol and water media. IL Farmaco, 60(2), 163-169. doi:10.1016/j.farmac.2004.12.002.

9. Chandra, P. (2012). Application of HPLC for the simultaneous determination of Aceclofenac, Paracetamol and Tramadol Hydrochloride in pharmaceutical dosage form. Scientia Pharmaceutica, 80(2), 337-351. doi:10.3797/scipharm.1108-04.

10. Moore, C. (2006). SumandeepRana, Cynthia Coulter, Determination of meperidine, tramadol and oxycodone in human oral fluid using solid phase extraction and gas chromatography-mass spectrometry. Journal of Chromatography. B, Analytical Technologies in the Biomedical and Life Sciences, 850(2), 370-375. 